\title{
Good Faith: The Law and Morality
}

\author{
Sylviane Colombo*
}

In the Uniform Commercial Code "good faith" is defined as "honesty in fact in the conduct or transaction concerned." Honesty, like good faith, is a moral category, and it is thus inevitable that the debate over the expansion of the good faith provision should take place mainly in the moral and ideological domains. It is precisely with these criticisms of good faith and the counter arguments to them that the present article is largely concerned. Much of the implicit resistance to - besides some explicit criticism of - good faith arises (particularly, one might add, in the United States) on the basis of the ideology of individualism. This is to be expected, as individualism is an integral part of the Anglo-American political and philosophical culture. My intention is to look at the philosophical basis of the individualist position in an attempt to uncover the roots of the resistance of classic individualism to the possibility of the expansion of the principle of good faith from its admittedly limited base in current American law.

The ideological weight of the individualist and liberal tradition in Anglo-American culture can hardly be overstated, and it is therefore worth an examination in depth. The ideology of individualism is often cited as an adequate intellectual defence in the face of those who urge for a greater degree of morality and compassion in human relations. It will be seen that not only are those who wish to hide behind individualism doing this ideology a great disservice, but also that individualism is a poor 'fig-leaf' in this respect. In fact, individualism as a philosophy is highly concerned with expanding the currency of moral issues of precisely the kind of which good faith is an example. This only begs the question why the ideological fig-leaf was considered necessary in the first place.

But if the main objections to the expansion of the principle of good faith are mainly ideological or cultural, one often finds that they are couched in other terms. And it is in this light - as an attempt, that is, to preserve a nineteenth-century conception of liberalism - that one should understand the concerns voiced regarding the economic

* Faculty of Law, University of Haifa

1. U.C.C. $\$ 1-201$ (19). This provision is concerned mainly with good faith performance. Good faith in negotiations is less dealt with, but it appears in the National Labor Relations Act $\$ 8$ (d) and in the Federal Truth in Lending Act. 
implications of good faith, on the strength of their deep-rooted belief in philosophical individualism (what is known as economic liberalism, although this too is a large river of ideas with many competing currents, of which by no means can it be said that all are inimical to the thrust of my argument). This misplaced economic emphasis draws attention away from the moral criteria that are at the root of the debate. Attention having been diverted and the moral arguments sidelined, discussion focuses on dubious (because prefactual) descriptions of the negative economic effects of good faith. These economic criticisms can be shown to be at best unproven, if not actually baseless. And while this is perhaps not the strongest aspect of good faith advocacy, these economic arguments have to be countered and the economic aspects brushed aside in order for the debate to concentrate on what is unquestionably the heart of the matter - the ideological and moral battleground.

Ironically enough, what is true of the economic aspects is often true of the "legal" objections to good faith as well (such as those relating to the nature of the law and of contracts, and the role of the judiciary). The legal objections too, like the economic ones, are a convenient distraction from the main issues of the debate. For law is not a disparate domain, but is - or should be - fully integrated into human existence and the needs of the society that it serves. ${ }^{2}$ The limited hard law that exists and the considerable degree of ambiguity in good faith and precontractual liability present a paradigmatic model that unless squarely faced will continue to dominate. To the extent that a party's behaviour falls comfortably within a market- or law-derived paradigm, the issue of good faith is muted or denied, and courts are relieved of the burden of coming to grips with the issue. Contractual paradigms, of course, exist in all legal systems and serve the useful role of contributing to the interpretation and integration of the law. Given the fact that their authority is based on tradition, the integration is in reality mostly a consolidation, and only rarely reflects change and advance as attention to the infinite variety of human behaviour would require. A new pervasive good faith perspective, instead, suggests a change, or rather an evolution, of the classic contractual paradigm.

The economic-oriented criticisms of good faith notions are the entire set of arguments that see a possible expansion of the notion of good faith as economically detrimental.

2. The legal objections rarely address specific cases, the reason being that there are practically no relevant cases in American law. I would note in this respect that also in Continental systems like Germany where the issue is extensively debated in theory, the practical cases are few. Two notable examples of the application (to a degree) of good faith are Sweden and Israel. But even in Israel where good faith has been receiving the most open and imaginative treatment, most notably by the Israeli Supreme Court, both the legislative and the judiciary have not yet faced the full extent of the problem, and there are still interesting contexts where the full-blown idea has not yet been explored. It is indicative of the problem of good faith that the distinctions drawn by Israeli courts are based upon levels of moral and ethical discourse and do not seek to introduce more instrumental or economic terms. The distinctions are more abstract and reflect a cultural tradition that accepts an intellectual system of rules and principles, and seeks the theoretical grounds on which to base concrete applications. 
Critics have claimed that it would hamper economic activity and would have no offsetting benefits in commercial conduct. ${ }^{3}$ More specifically, it has been claimed that as it is, the good faith performance doctrine raises the costs of contracting, and the duty to bargain in good faith at the precontractual stage would only raise these costs even further, not only in terms of the costs of negotiation but also because the responsibilities of the parties as originally bargained for and allocated would go well beyond their contemplated allocations of risks. But this is a short-sighted argument (as are many of the economic justifications for the non-imposition of a duty of good faith) as in the long run the adoption of a generalised good faith requirement would actually work toward reducing costs. ${ }^{4}$ As one commentator has noted:
"the good faith performance doctrine may be said to enhance economic efficiency by reducing the costs of contracting. The costs of exchange include the costs of gathering information with which to choose one's contractual partners, negotiating and drafting contracts, and risk taking with respect to the future. The good faith performance doctrine reduces all three kinds of costs by allowing parties to rely on the law in place of incurring some of these costs.",5

And while reference here is made specifically to performance, in fact the implications for negotiation are evident and implicit in his argument. Generally speaking, from an economic viewpoint, the precontractual good faith duty raises the level of mutual trust in the business integrity of the parties, thus making contracting less expensive.

A somewhat different tack is employed by the common criticism that good faith would raise administrative difficulties and administrative costs. The reasons usually are the nebulousness and vagueness of the concept of good faith, and that ". . . the

3. Kessler and Fine, "Culpa in Contrahendo, Bargaining in Good Faith, and Freedom of Contract: a Comparative Study, 77 Harv. L.R. 401 (1964), at p.449 speak of the "real danger in any overenthusiastic and indiscriminate embracing of good faith notions" and state that "a deterioration of the law of contract into 'well meaning sloppiness of thought' must be avoided so as not to disregard the fundamental moral principle of responsibility for one's own actions." However they acknowledge that "good faith and culpa in contrahendo, used with restraint, are 'residual' categories whose existence is vital to an open system of contract justice and to a restriction of contractual freedom in the interest of its own preservation." Farnsworth, "Precontractual Liability and Preliminary Agreements: Fair Dealing and Failed Negotiations", 87 Columbia L.R. 217 (1987), at p.243, argues that: "(t)he difficulty of determining a point in the negotiations at which the obligation of fair dealing arises would create uncertainty. An obligation of fair dealing might have an undesirable chilling effect, discouraging parties from entering into negotiations if chances of success were slight. The obligation might also have an undesirable accelerating effect, increasing the pressure on parties to bring negotiations to a final if hasty conclusion. With no clear advantages to counter these disadvantages there is little reason to abandon the present aleatory view" (emphasis added).

As suggested by Feinman, "Promissory Estoppel and Judicial Method", Harv. L. R. 3 (1984) 678, at p.716, the present complex economic and social setting, however, now demands it. Furthermore there is a greater sensitivity to the issue of substantive justice (this is proved, among other things, by the attention paid to one-sided contractual ordering and by the emergence of the doctrine of unconscionability, which within its protection of the weaker party shows an element of Continental culpa in contrahendo).

4. It could also enhance contract's efficiency. If reliance costs are apportioned between the parties, this will encourage them to assess the risks and opportunities of negotiating.

5. Burton, "Breach of Contract and the Common Law Duty to Perform in Good Faith", 94 Harv. L.R. 369 (1980), at p.393. 
vagueness problem is not suited to temporal solutions."6 An example of such a commentator that epitomises the prevalent critiques of good faith that are presented as rational economic arguments is Clayton Gillette. He asserts that the costs of interpretation, administration and remedy would increase and intensify if one were to move from good faith prohibiting limited notions of dishonesty to a more expansive notion, and "may multiply to an unacceptable level if good faith is used to police the substantive fairness of a transaction or to convert commercial actors into brothers' keepers. "7 But vagueness - or rather openness - of the concept can be viewed positively rather than negatively even economically speaking. Indeed, even if administrative costs were to turn out to be higher than they are at present (which is far from certain), the unsuitable "vagueness" would serve as an excellent deterrent against bad faith, thus actually lowering the overall market level of administrative costs. ${ }^{8}$ Moreover, the overall operational standards can be articulated in a relevant measure, thus eliminating much of the "vagueness". 9

This is particularly true given the fact that as matters stand now one would be hard put to describe the field of commercial transactions as one in which there is a substantial consensus on economic legal norms. Jay Feinman notes that "there simply does not exist an agreed set of principles and practices of commerce. In many contract cases,

6. Gillette, "Limitations on the Obligations of Good Faith", Duke L.J. 619 (1981), at p.645. The vagueness of the good faith concept should actually be seen as an attitude rather than a specific result of conduct. 7. lbid., at p.632 (emphasis added). It is the ultimate irony that the use here of this morally rich connotation is meant to scare the reader away from morality. The question of the separation of the economic sphere from other concerns is itself a matter of debate (and it would be wise to remember, in the context of Gillette's biblical connotation, that economic struggle was the cause for the slaying of Abel. Nor would a criticism from a feminist perspective employ "good Samaritanism" negatively, as Gillette does. Commenting at p. 635 on the U.C.C. ambivalence toward imposing duties of assistance in certain situations, Gillette notes that:

"one of the most blatant rejections [of the notion of good Samaritanism] is found in section 1-203 itself. Its failure to extend the good faith obligation to the negotiation process apparently reflects a deliberate choice to permit parties to refrain from disclosing material information to others."

One can perceive here a measure of complacency. The inference is clear: "others" are automatically taken as implying "enemies".

8. If for a while a pervasive good faith notion might appear to raise administrative costs, we must consider how a culture of good faith will in the long run affect the system and the parties. We can venture that an ethical proposition will affect sensibilities. The system requires adjudication, and thus entailment of administrative costs, unless the parties can agree. Once the moral precept influences human behaviour, the benefits will outweigh the costs and the risks, if any. Ultimately this will prove positive in terms of how society allocates resources.

Transaction costs represent a strong argument against extending the good faith requirement. They may well be overstated. The question is whether society is prepared to take on these costs, not on the ground that the individual transactions justify it, but because of the symbolic importance and more general consequences of such choice.

9. The current developments in Israeli law are a prime example of the manner in which this objection may be satisfactorily overcome. And after all, one should acknowledge the existence of a considerable degree of uncertainty and inconsistency in adjudication in general. In this good faith would not be unique. 
the problem is precisely that the parties do not share beliefs on what is appropriate commercial behaviour. Whether a supervening circumstance constitutes an excuse for nonperformance of a contract, for example, is a basic conflict of value embodied in impracticability cases. "He also remarks on the circularity of the concept of empirical norms:

"The law presumably is one factor shaping standards of social and especially commercial behaviour. People's 'expectations' and merchants' notions of 'good faith' are to some extent dependent on the positive, public expression of norms by contract law itself. Thus, it is circular to define those normative expressions on the basis of the nonlegal situation." 10

"Once contract law is understood as simply an area of policy dispute", he concludes, "the next task is to attempt to order the discipline." There is no logical cause to object to good faith being part of this new discipline. If a more demanding good faith provision increases the risk to the promisor by the means of a legal guarantee of performance or substitute to the promisee, one should remember that "all tend to be both promisor and promisee at different times. Whether enforcement reduces total uncertainty and thereby promotes exchange and commerce is thus a complicated empirical question, not a theoretical one. Further, custom, belief, or economic power may be more important factors than legal sanction in preventing distrust." 11

An additional major criticism that belongs to the category of economic and quasieconomic arguments is the objection that points to the difficulties connected with the definition and regulation of "good faith" that are necessary in order to assess its economic equivalent and providing remedies for its violation. To this one might note that good faith provisions are vital elements in European legal systems and remedies for their violation are provided for. ${ }^{12}$ Moreover, there are already in place remedies in American law which could be, and in fact are, used for most instances in which a clear-cut notion of good faith in the culpa in contrahendo context would otherwise provide a more direct solution. ${ }^{13}$

10. Feinman, "Critical Approaches to Contract Law", 30 U.C.L.A. L.R. 4 (1983) 829, at p.837.

11. Feinman, supra n.3, at p.841.

12. Powell, "Good Faith in Contracts", 9 Current Legal Problems 16 (1956), at pp.32-35.

13. Farnsworth, supra n. 3. In the past thirty years there has been in America, with the exception of the Kessler and Fine, and Farnsworth studies, practically no interest in an examination of good faith at the bargaining stage. This is not to say that concepts similar or related to the adoption of a good faith principle in the negotiating stage have not been studied, but a straightforward concept of good faith akin to that provided for by culpa in contrahendo has not been their primary focus.

As a non-exhaustive listing of these studies, I would mention those on the evolution of estoppel and the protection of reliance interest from the 16th century theory of assumpsit to its present day expansion; on the nexus between equitable estoppel and promissory estoppel; on the evolution of consideration and on the language of section 90 of the Restatement and the opportunities it offers to dispense with technicalities of definition to enlarge the traditional scope of enforcement for bad faith representation, freeing promissory estoppel from classic consideration doctrines and notions of gratuitous promises (see, generally, Powell, 
To sum up the arguments listed above whose rationale is economic, one should note as a reminder and general caution that economic prophecies have notoriously been lacking in success despite claims to the contrary by modern economists. Ultimately, of course, prior to the event one cannot judge with certainty the economic impact a good faith bargaining duty would have on the system, but there is ample ground to think that it would be far removed from being the market catastrophe that some would have us believe.

\section{II}

The economic objections to good faith in precontractual negotiations go far deeper than a cost-benefit analysis and an attempted - albeit shaky - calculation of the effect a de facto good faith requirement would have on individual contracting parties and on the market as a whole. For the concept of a good faith requirement in general, and to a far greater extent the possibility of a legal duty of good faith arising out of precontractual negotiations strikes at the root of the ideological underpinnings of non-Marxist economic theory, and also at the roots of the unique phenomenon of intertwined economic and political thought that has typified the mainstream of Western political philosophy and culture since the Renaissance.

The crux of this line of argument (an argument that is as culturally ingrained as it is intellectually driven) is that the duty of good faith represents an unwarranted intervention and an undue interference of a third - essentially foreign - party in what is after all a matter to be decided between the contracting parties. The suggested good faith requirement would restrict the market freedom of the negotiating parties. Needless to say, there is a long tradition of opposition to the curtailment of market

supra n.12; Henderson, "Promissory Estoppel and Traditional Contract Doctrine", 78 Yale L.J. 343 (1969); Summers, " 'Good Faith' in General Contract Law and the Sales Provisions of the Uniform Commercial Code", 54 Va. L.R. 195(1968); Comment, "Expanded Application of Promissory Estoppel in Restatement of Contracts section 90", 65 Mich. L.R. 351 (1966); von Mehren, "Civil Law Analogues to Consideration; An Exercise in Comparative Analysis", 72 Harv. L.R. 1009 (1959); Patterson, "An Apology for Consideration', 58 Columbia L.R. 929 (1958).

There are also studies on the remedies and rationales for action-in-reliance, that discuss the alternative merits of reliance damages and full damages including opportunity costs, of a single measure of damages versus a flexible approach, of commercial and non commercial settings (see, generally, Comment, "Once More Into the Breach: Promissory Estoppel and Traditional Damage Doctrine", 37 U.Chi. L.R. 559 (1970); Fuller and Perdue, "The Reliance Interest in Contract Damages" (parts 1-2), 46 Yale L.J. 52, 373 (1936); Henderson, ibid.).

In addition there is the debate over the relation between relief in tort and in contract, from discussion on the dissociation of promissory estoppel from contract (Henderson, ibid., at pp. 378-9), to the advisability, or " absurdity" of preserving the contract-tort dichotomy (see, generally, G. Gilmore, Death of Contract (1974); C. Fried, Contract as Promise (1981).

There is increasing recognition of and debate over the "contract to bargain"; over problems of firm offer and preliminary agreements in general (see, generally, Knapp, "Enforcing the Contract to Bargain", 44 N.Y. U. L.R. 673 (1969); Farnsworth supra n.3).

Finally, there is some discussion on the duty to bargain in good faith in the domain of labour contracts and its potential relationships with commercial contracts to bargain. 
freedom in any form. What is worse, the argument continues, is - and this perhaps is the real anathema - that the outside interference in the market situation would be in the person of a judge, who is none other than the representative of the state. Concern is typically expressed that extending judicial discretion will come at the expense of:

"the individual's freedom to plan and order his own life and [will bring about]

a corresponding growth in the power and paternalism of the state". 14

These concerns go back to Adam Smith, the symbol perhaps for the entire intellectual philosophy underlying the institution of contract as a device to allow individuals to plan (as opposed to central planning). His thought, directly or indirectly, is at the basis of all present-day economic thinking; his concept of the "invisible hand" long ago captured the ideological centre-stage, and rightly serves as the epitome of the nineteenth-century European liberal (and modern-day conservative) conception of the interaction of homo economicus. ${ }^{15}$ At its base is the idea of free-willed rational action on the part of the individual in the market place. Not only is each individual responsible for himself alone but is driven by egoistic desires. Indeed it is one of the fundamental requirements of this economic model (as it is, after a different mode, of that of classic Marxian economic theory) that homo economicus acts strictly according to his best rational egoistic interests, without thought for other members of society. Moreover - and here is the linchpin of this model of an "economic miracle" - by adherence to this blueprint of indifferent calculation and pulse-quickening greed the utilitarian ideal of "the greatest happiness" is achieved and cold uncaring (economic) justice meted out. It is a belief in the appropriateness and the supremacy of the concept of "division of labour" in which the emphasis on "division" in society is paramount.

The political and philosophical impact of this economic theory (and, one should add, its resilience) is well known and amply documented. It has had an evident influence on the development of political philosophy, and is at the root of Western democracy. If the guiding hand of the market is "invisible", which is to say non-existent other than in the form of the sum of the various individual actions (rather like an erratic and unpredictable weather system without a harmonising and retributive deity to govern it), the political parallel clearly is of sovereignty which is not vested in any individual or regulatory board, but rather is to be found in the amorphous aggregate body of the citizenry (or, in a different way, the nation). Here too, there is no "artificial"

14. Atiyah, "From Principles to Pragmatism: Change in the Function of the Judicial Process and the Law", lowa L.R. (1980) 1249, at p. 1272.

15. In fact, however, the "invisible hand" is just a fleeting image in An Inquiry into the Nature and Causes of the Wealth of Nations (IV.ii): "[The individual] intends only his own gain, and he is in this, as in many other cases, led by an invisible hand to promote an end which was no part of his intention." The phrase is also found in his The Theory of Moral Sentiments. 
or "external" guiding hand, and the ship of state is at the mercy of the moody members of its crew. But again, and this point bears repeating, it is precisely this mass of base human desires and egoistic motivations that is judged to be providentially the most felicitous for the overall health of the body politic.

In order to examine the heart of the ideological resistance to the expansion of moral criteria in the law, as reflected in the opposition to the good faith principle, I shall be looking in the next three sections at three thinkers who were among the most influential in shaping classic nineteenth-century individualism: Immanuel Kant, David Hume and John Stuart Mill. The importance of Kant to this discussion is that besides being one of the most influential Western philosophers and the central pillar of a particular school of individualism, he strikes a familiar chord in the Anglo-American philosophical tradition. Kant stood of course largely outside this tradition (although he was to a considerable degree influenced by it, particularly its Scottish and Irish branches). The introduction of Hume and Mill in the context of this discussion calls, I believe, for no explanation. Starting with the Kantian conception of individualism and its moral assumptions (which, it will be seen, has much in common with the Anglo-American tradition, particularly the Protestant ethics of duty and morality $\left.{ }^{16}\right),{ }^{17}$ I shall delineate the stand of each of the three with respect to individualism. For each of the three I shall also discuss the role of the state in a liberal society. Finally, after this exposition of the complex philosophical web that in the English-speaking world is alternately called individualism and liberalism (terms that in the main overlap, although they do not quite coincide), I shall comment on the implications of this philosophy for the wider topic under consideration.

\section{III}

Kantian freedom is the freedom of the Wille - the will to do what is morally good - in a situation where moral responsibility of the noumenal (rational) agent is present (freedom of the Willkür). Morality for Kant lies wholly within the range of rational concerns and actions of the individual. Within this realm there can be no room for emotions because emotion as a subjective feeling par excellence is a priori irrational. As emotion is, according to Kant, a passive reaction in man and hence beyond the scope of his responsibility, any action that is determined by emotion can only be unprincipled, and is thus found lacking in this quintessential characteristic of morality.

16. This synthesis like any other - but perhaps especially so given its intricate (and at times abstruse) subject matter - is fraught with the dangers inherent in trying to draw any picture in broad lines. Taken as a whole, despite the troubled waters of the continuing debate over their precise content and boundaries into which I shall not venture (for Kant is often intentionally vague), one can talk of Kantian individualism and Kantian morality. Suffice it here to say that, as is often the case, it is mainly in their derived - and therefore by needs synthetic - form that they have been influential.

17. Although strictly speaking an eighteenth-century philosopher, Kant is often placed (with good reason) in the framework of the nineteenth-century Continental philosophy whose course of development he largely directed. 
The unbridgeable gap in Kantian morality between reason and feeling bears stressing. ${ }^{18}$ It is only by withdrawing from any emotional response that the individual repossesses the initiative and the obligation to act morally, which in this light acquires a purely intellectual content. ${ }^{19}$ For morality in the Kantian view is a matter of principle: it is impartial, and cannot take into account emotional whims, individual (and hence subjective) cases and situations, nor indeed anything that falls short of the universal. The moral person is guided in his or her duty by the abstract, not by the contingent. In short a moral action - viewed essentially in terms of obligation - can only be such an action which would readily be embarked upon by any noumenon in a like situation. It is a view that is unyielding and uncompromising in its austerity and which has had a very influential history. "It is important to see," writes one commentator, "that these lines of thought do not spring solely from explicit philosophical thought. Rather, they have roots also in our own moral culture. The Kantian view has obvious affinities with a definite Protestant tradition of morality - the emphasis on subjection to duty, on control of feelings and inclinations, on strength of will in resisting impulses and inclinations from one's selfish lower nature, on conscientious action on principle, rather than emotional spontaneity. That tradition has deeply affected the moral thinking and experience of Anglo-Americans." ${ }_{20}$

The underlying assumption beneath Kantian morality is the freedom of the moral actor, or in other words the freedom of the will. ${ }^{21}$ The Kantian individual is a noumenon able to make his own moral choices regardless of the phenomenal conditions of his circumstances. Morality, particularly if seen in terms of duty and obligation, presupposes choice and the freedom to choose correctly, i.e. according to moral criteria. ${ }^{22} \mathrm{Of}$ course the freedom of the will is in effect immediately restricted again by Kant, both in the practical sense that duty-bound to act thus rather than otherwise the range of choice open to the individual is limited, and in the more profound sense

18. In the post-Freudian world there is hardly any need to point out that this dichotomy between reason and the emotions is on extremely shaky ground, to say the least. It is however interesting to note that no lesser eighteenth-century empirical philosopher than David Hume strove to drive home the point that the intellect is governed by the passions, and that precisely in the field of morals "reason of itself is impotent" and hence "the rules of morality . . . are not the conclusion of our reason": quoted in Hayek, "The Legal and Political Philosophy of David Hume", Hume, Modern Studies in Philosophy. A Collection of Critical Essays (1968) 335, at p.343. Hume's recognition of the fragility of reason in face of feeling is also the central theme of Norman Kemp Smith's groundbreaking study The Philosophy of David Hume (1966).

19. However, on a different level Kant does admit that in practice the recognition of what the moral duty consists in is intuitive. This was to be one of the foci of the Hegelian critique of Kant.

20. L. Blum, Friendship, Altruism and Morality (1980), at p.3.

21. The same assumption holds true for the entire range of liberal philosophers in the English-speaking world with the crucial difference that they imbue this freedom with different content.

22. See, for instance, R. Walker, Kant (1978); R. Scruton, Kant (1982); also H. Williams, Kant's Political Philosophy (1983). The existence of man as a free noumenal being is one of Kant's postulates of pure practical reason, the metaphysical edifice rendered necessary, according to Kant, by morality; the other (even shakier) postulates are the immortality of the soul and the existence of God. While Kant argues in the Critique of Practical Reason that freedom is a necessary outcome of man's consciousness of the validity of morality, in his earlier Grundlegung, conversely, it is on the basis of man's freedom of action that he derives the validity of morality. 
that the individual being a noumenal agent, it is possible at least in theory to predict the rational (and therefore moral) course of action which he or she will adopt. This limitation and predictability might not seem to sit together well with freedom of the will, but according to Kant (as is well known) freedom is not the freedom to act but rather the freedom to desire the morally correct, that is freedom understood on the intimate and formative level of the ability of the noumenal agent to reshape and remould his or her self-consciousness (or character) ${ }^{23}$ While this goes against the grain of mainstream Anglo-American empiricist thinking on the nature of freedom, it did in fact find a surprising echo in perhaps the most renowned English advocate of liberalism and individualism, John Stuart Mill, who paid tribute in his classic work On Liberty to the Continental Protestant individualist tradition. Mill insisted that Germany was not devoid of intellectual liberty and that consequently "my little book is . : . as little needed in Germany as it is much here." 24

Kantian individualism - in its political as opposed to its moral context - has remained by and large outside the mainstream of the Anglo-American philosophical and political tradition. To the extent that it did converge on the latter on some crucial points, this was through its close historical and cultural affinities with the political philosophy of Protestantism - the same root from which sprung classic liberalism, being the political ideology of the Glorious Revolution and the Whig Party. Protestantism, both as a natural development of some of its religious tenets (in particular those associated with such branches as Calvinism and Presbyterianism), and also as a result of its historical evolution in early modern Europe, traditionally stood for freedom of conscience (in a close religious sense) and by philosophical extension for the rights of the individual in society in general. ${ }^{25}$ In Germany, however, the strictly religious context of the freedom to achieve personal salvation underwent a ready transformation in the hands of German philosophers, and first and foremost by Kant himself, into a moral, "intimate" freedom shorn of religious trappings, with the (for Kant) necessary exception of the existence of God as the fountainhead of morality. The internalised moralistic aspects of this "freedom" were given added impetus in a situation where freedom of the kind associated with the tradition of English personal and political liberty was unknown.

23. This internalisation of freedom, and hence of choice as well, also serves the need to come to terms with the problem of determinism and the theory of causation (the Principle of Sufficient Reason) in the phenomenal world.

24. See B. Semmel, John Stuart Mill and the Pursuit of Virtue (1984), at pp. 164-165. "Living under the petty despotisms of their duchies and principalities," notes Semmel, "the German philosophers had exalted the freedom of self-realisation, which was clearly akin to the Protestant insistence on a believer's right to seek his own salvation, and similarly feasible even in the absence of political liberty. " Mill also used a Kantian argument of freedom to counter accusations that he negated freedom by accepting an almost "Asiatic fatalism" in his Logic. Ibid., at p.50.

25. However much this was true in theory, the practice of Calvinist societies in Switzerland and Scotland, and of the Puritan ones in England and New England, was somewhat different. 
If to Mill the intellectual grass may have seemed for a while greener in Germany than it was in England, as it certainly appeared to Carlyle and his school, this did not mean that Mill was blind to the most crucial difference between what he understood by individualism and what German individualism implied, namely the existence (or lack) of a political and social terrain in which to put individualism to practice. Mill, while sympathetic to Kantian individualism on some scores as were many English proponents of classic liberalism, ultimately had to part ways with it (and again, he was not alone in so doing) on account of its greatest deficiency - its failure to advocate personal political freedom and individual political rights. ${ }^{26}$ For where Kantian individualism advocates the internalisation of the notion of freedom coupled with self-subjection to external authority, in the Anglo-American world the primary and crucial connotation of freedom is of course political, finding its characteristic expression in the idea of individual rights. ${ }^{27}$

As a true individualist Kant assigns to the existence of the state the role of enabling individuals to pursue their own private interests. ${ }^{28}$ This is Kant at his most liberal. The Kantian implications of this position, however, are profound. As the role of the state is described in terms of making possible the realisation of the categorical imperative of the individual, the state itself, from having a purely functional character, is endowed with moral quality. As a result political duties become an integral part of the moral duties in general of the individual. The social and political relations, and in particular the political obligations of the individual with regard to civil society thus become a moral concern subject to all the qualifications and empirical restrictions that Kantian morality implies. Most important of all perhaps, Kant derives from this the a priori legitimisation of government and its moral authority to coerce unwilling or recalcitrant citizens. Needless to say, the individual has a moral obligation to be part of civil society, which means that he can (and should) be compelled to be part of it. "This means that the bonds which tie us to others in civil society (and which thereby legitimate public authority) are distinctly moral bonds, rationally derivable from our general moral obligations to others. They thus do not depend on any voluntary act, whether it be consent, tacit consent, or hypothetical consent . . .",29

The state, then, as the embodiment of civil society is a necessary organisational

26. Despite his belief, following Rousseau, in the republic as the most suitable form of political organisation and his sympathy for the ideals of the French Revolution, Kant severely and repeatedly admonished against attempts at unseating the existing sovereign. To avoid the implicit contradiction in this, Kant was obliged to resort to the lame device of claiming that political society was in a continuous process of an ever-closer approximation to the Highest Good. Kant, in the words of one Kantian scholar, "always aims to keep his head unbloody and yet unbowed': Williams, supra n.22, at p.136. A liberal in principle, Kant thus often turns out to be an arch-conservative in practice.

27. Another way to put this would be that Kant is primarily concerned with the source of freedom, Mill with its scope.

28. Williams, supra n.22, at p. 164

29. Pippin, On the Moral Foundations of Kant's Rechtslehre, The Philosophy of Immanuel Kant (1985), 107 , at p. 108. He adds: "Even in a natural society of benevolent agents, who vote unanimously to remain in their state of nature, such a duty and warrants hold unequivocally." See also Murphy, "Hume and Kant on the Social Contract", Philosophical Studies 33 (1978), 65. 
unit, and hence participation in it is, according to Kant, obligatory. This is a far cry from Rousseau, even though the starting point is similar. For Kant, taking up in this respect a position halfway along the spectrum between Rousseau and Hobbes, the rights of the individual in the state of nature are at best 'provisional' because of the constraints of the phenomenal world. It is only within the framework of civil society that the rights of the individual are guaranteed and become therefore 'peremptory'. If, following Rousseau, Kant accepts the concept of the General Will, this is only by way of saying that civil society is what every noumenon would choose given the hypothetical circumstances of such a decision to be made and rational agents to make it. The General Will thus falls under the category of Wille, not of Willkür, and it is a rational and moral obligation. Not that Kant believes that an original social contract as such was ever agreed upon historically. Rather, like Hume, he accepts this fiction as a convenient method for the philosopher to assist him in the explanation and elaboration of the nature of the state and civil society. ${ }^{30}$

What are the rights that the Kantian state guarantees the individual? In practice Kant makes it clear that he is thinking primarily of the property rights of the individual. More generally however, Kant says in a true liberal vein, they are all such rights (and, one might add, all such conditions) as allow and encourage the maturation of the fundamental right of the individual to freedom. ${ }^{31}$ As the raison d'être of the state this is crucial, for from this fundamental duty of the state towards the individual Kant derives the moral obligation of the state to maintain and protect itself. In short, the stability of the state becomes an end in itself, an end which the Rechtslehre obliges the individual to support actively. ${ }^{32}$ In this light, revolt against authority is impermissible and morally wrong under all circumstances. Moreover, it is from this principle that Kant derives the right (translatable under the necessary conditions into the duty) of the state to levy taxes and armies and to set up a police force. In addition, it is interesting to note that it is on this ground that Kant advocates a system of social welfare when necessary; not, that is, on the basis of a moral obligation to help other individuals (as such this would come under the category of a Kantian duty of virtue) or in order to share wealth, but as a purely political expedient (where advisable); an almost Machiavellian mechanism in order to protect the stability of the state itself.

As has been stated, Kant's defence of the power of the state is argued in basically liberal terms, on the grounds that "the ony legitimate interference with the free activity of citizens is that which can be shown to secure or protect freedom." ${ }_{33}$ The autonomy of every individual has to be respected, and each individual regarded as a rational end in itself. Interference with the liberty of the other is thus permissible only if the actions of the individual in question conflict with the universal rule (and

30. Walker, supra n.22, at p. 162.

31. Ibid.

32. Ibid., at p.161.

33. Pippin, supra n.29, at p.121. 
its rational implications) according to which all humans are to be perceived as national ends. This is essentially very similar to the concept of "negative" liberty, according to which the sole limitations on the actions of the individual in civil society are in those cases where they conflict with the rights of other individuals' rights that are equal to his own. However, the crucial difference between Kantian and Millian liberalism is of course the fact that Kant sets out a noumenal guideline that is forceful in principle (although it is overly schematic to be of much use in practice) against which the compatibility of the actions of the individual are to be judged, whereas for Mill and classic liberalism the test is always (to remain within Kantian terminology) in the phenomenal world. In an ideal situation in which the phenomenal decisions of each and every individual in civil society always coincided perfectly with the noumenal, there would not be much disagreement between Kant and Mill, except - and this is a considerable exception - on the basic need for the continued existence of civil society as such. As things stand however, in practice they remain wide apart.

For Kant, as for all liberals, the authority of the state implies the rule of law under which all citizens are equal. The fact that in practice Kant accepted and condoned the stratification of society does not weaken his belief that in principle all citizens are equal. Certainly, and this is true in the case of a stratified society as well, Kant believes that, similar to the situation in medieval society from which the Prussian society of his day could hardly claim to have evolved politically beyond recognition, all subjects who belong to a similar political category should receive equal treatment from the law. The only exception that is recognised by Kant to the rule of equality before the law is in the case of the sovereign acting in his political capacity. For Kant the sovereign is the embodiment of Justice in the state and therefore the justice of his actions cannot rationally be called into doubt (apart from the political inadvisability, from the viewpoint of the stability of the state, to do so). In this, one commentator notes, Kant is espousing a Hobbesian view of sovereignty, one that lies outside the liberal tradition. ${ }^{34}$ However one should also note that sovereignty is not an essential element of the political philosophy of Kant who was at heart a republican. ${ }^{35}$

34. See Williams, supra n.22, at p. 126.

35. Strictly speaking, and this is a point well made by Isaiah Berlin, the liberal principle does not logically entail any particular form of government: "Self-government may, on the whole, provide a better guarantee of the preservation of civil liberties than other régimes, and has been defended as such by libertarians. But there is no necessary connection between individual liberty and democratic rule. The answer to the question 'Who governs me?' is logically distinct from the question 'How far does government interfere with me?' It is in this difference that the great contrast between the two concepts of negative and positive liberty, in the end, consists. For the 'positive' sense of liberty comes to light if we try to answer the question, not 'What am I free to do or be?', but 'By whom am I ruled?' or 'Who is to say what I am, and what I am not, to be or do?' The connection between democracy and individual liberty is a good deal more tenuous than it seemed to many advocates of both": I. Berlin, Two Concepts of Liberty, Four Essays on Liberty (1969), at pp. 130-131. 
The Kantian noumenan submits willingly to the authority of the law. Strictly speaking of course, this cannot be called submission as the Wille of the individual is at one with the law which is the crystallisation of noumenal choice. The criminal in civil society is also called upon by Kant to submit willingly to punishment according to the dictates of the rational law, for in committing a crime the individual has in effect renounced his rights in society. These rights can only be restored to him upon the completion of his term of punishment. ${ }^{36}$ The renunciation of these rights is not seen by Kant primarily in terms of a penalty for having broken the social contract, in the sense that by committing a criminal act the criminal forfeits his political rights in civil society. Rather the criminal deed is an indication of the loss of moral status, evidence on the part of the criminal of his sorry condition in terms of his noumenal self, and it is this moral autonomy that can only be regained through suffering punishment.

The danger (from a liberal perspective) is of course that the law, as it is regarded as the embodiment of the rational, does not, indeed cannot from a Kantian point of view, deprive the individual of his freedom, as his noumenal freedom would at all events lead him to act in accordance with precisely the same laws. "With this," a contemporary liberal thinker writes,

" "the door was opened wide to the rule of experts. . . . If you fail to discipline yourself, I must do so for you; and you cannot complain of lack of freedom, for the fact that Kant's rational judge has sent you to prison is evidence that you have not listened to your inner reason, that, like a child, a savage, an idiot, you are not ripe for self-direction or permanently incapable of it." ${ }^{37}$

\section{IV}

For Hume the term "individualism" is, technically speaking, void of meaning. Following Berkeley, he claims that one's self-image consists of, in his terminology, "impressions", ${ }^{38}$ and as "impressions" are fleeting and unstable one can have no lucid, continuous and coherent understanding of oneself. ${ }^{39}$ What then draws the

36. Kant, it will be noted, is also a firm and merciless believer in capital punishment.

37. Berlin, supra n. 35 , at pp. 152-153.

38. Hume makes a distinction between "impressions" and "perceptions," which despite passing similarities is not equivalent to the Kantian distinction between "intuitions" and "concepts".

39. See A. Ayer, Hume (1980), at p.51; also I. Berlin, The Age of Enlightenment (1979), at p. 176. In this Hume is also in explicit opposition to Descartes and Leibniz who maintained that the essence of the soul, the core of the individual around which the human perceptions collected, endured. By comparison, empiricists had no qualms about (and almost, one would add, no interest in) the problem of the self in this context. The ultimate in this direction was of course reached in classical Benthamite utilitarianism (see, for instance, W. Thomas, Mill (1985), passim). For Hume's exposition of his views on the subject see the renowned section "Of Personal Identity", Treatise of Human Nature, I,IV (vi). 
disparate fleeting image into one whole? "Hume barely attempts to give an answer and in one of the Appendices to the Treatise, he admits his failure to find one, and indeed views the whole question of personal identity as posing a problem which he cannot solve." 40

All this of course is not to say that Hume was not an individualist in the political sense of the word as we understand it. On the contrary, far more perhaps than any other political philosopher of his age, and arguably even more so than Locke, Hume was (although not in any direct official sense) the philosophical mouthpiece and the doctrinaire par excellence of the Glorious Revolution and hence of legal and political liberalism. And it was he who gave the clearest expression to the concept of freedom under the law, an idea that later would find its way via Kant to the theorists of the Rechtsstaat. ${ }^{41}$

For Hume, as for Kant, freedom of the will is not unlimited, but for Hume this means that there are always underlying causes for any particular action we choose to take, ${ }^{42}$ even though we may prefer - in particular when thinking of ourselves rather than of others or of the-concept of freedom in general - to believe that we do in fact function as free and unhindered agents. In contrast to Kant, ${ }^{43}$ Hume stresses liberty of action (as opposed to freedom of the will) as the foundation of moral behaviour. For Hume, as already stated, morality is essentially non-rational, reason having no control over morality. He regards such things as "love of children, gratitude to benefactors, pity to the unfortunate" as moral acts and also, importantly, sees them as natural reactions. However, Hume does not consider morality as a sense of justice that is inherent in the individual. Rather he sees morality as (to use his terminology) an "artifact", or in other words a result of society's progress. This is a point to which I will come back shortly. For the moment however, I wish to emphasise the polar difference in their attitude towards morality between Kant and Hume. For Kant morality stems from duty, that is from the objective recognition

40. Ayer, supra n.39, at p.52. One of Hume's attempts to overcome this problem is by the introduction of the force of custom as the element that binds together the separate images of the non-identical self (over time) into a whole that in terms of time span is relatively consistent. Simultaneously, however, it is personal experience (or life itself)) that is responsible, according to Hume, for the inconsistency of the self. In his use of the concept of "custom" Hume shows his indebtedness to Roman political thought (and above all to Cicero) and to the French seventeenth-century philosophers. See P. Jones, Hume's Sentiments (1982), at p.152 et seq.; also McIntyre, "Is Hume's Self Consistent?", McGill Hume Studies (1979), p.79; also J. R. Weinberg, Ockham, Descartes, and Hume (1977), at p.113 et seq.

41. Hayek, supra n.18, p.353.

42. Hume's theory of causality is central to his thought, and indeed is one of his major philosophical contributions, especially in his exposition of the problem of induction. It is also one of the dividing lines between Hume and Kant.

43. The question of the degree to which Kant was influenced by Hume's work is an interesting one, as is also the question of the influence of Hutcheson on both these philosophers. See, for instance, Beck,

"A Prussian Hume and a Scottish Kant", McGill Hume Studies (1979), p.63. 
that a specific act is inherently moral (thereby bestowing upon the act the accolade of Kantian freedom), whereas for Hume it is precisely this type of motivation the recognition of its morality, or in other words a sense of duty - that invalidates the morality of the act, as action out of a sense of duty does not confer merit on the individual. ${ }^{44}$ If for Mill (with one foot in the utilitarian Benthamite camp) "the greatest happiness of the greatest number" is, or should be, the overriding moral principle of every human being, and morality is a matter for the individual, for Hume morality can only be considered within the context of the existing social consensus, and therefore insistence on the "greatest happiness of the greatest number" is in a fundamental sense tautological.

The importance of this comparison is to show that both diverging currents (and their degree of divergence is readily apparent) are recognisable within the framework of Anglo-American individualism as it evolved. Furthermore, it drives home the point that discussing the nature of individualism immediately draws us to a discussion of morality. Ultimately, and this is a point that I will return to, none of the major thinkers in the Anglo-American philosophical tradition can afford to do away with morality (or in fact even wishes to do so), and even as unrelenting a sceptic and hard-nosed an empiricist as Hume stresses the importance of benevolence in human actions and concern for the good of the other. Individualism denuded of its morality (and thus of its humanity) not only does historical injustice to this noble philosophical tradition, but also is in itself something unrecognisable and barbaric, beyond the fringe not only of liberalism but of anarchism as well.

As we have seen, for Hume morality is a social "artifact". This immediately raises the question of the social context within which individual morality is to be placed. Hume believes in an evolutionary process of the formulation of social structures which in its implications for the nature of humanity is almost Hobbesian in its bleakness. Sceptical to the end, he admits to his inability to come up with a definitive argument for the need to be just or to maintain promises. ${ }^{45}$ Rather, in his view, it is the historical contingency, a set of particular circumstances, that have caused society to evolve and with it "the necessity of human society", the "three fundamental laws of nature", of "the stability of possession, of its transference by consent, and of

44. Ayer, supra. n. 39, at p.878. "We must", Ayer emphasises, "avoid being misled by Hume's saying that actions are morally good only as being signs of a good motive or a good character. It does not mean that he conceives of characters or motives as being good in themselves. They owe their goodness only to the fact that they habitually give rise to actions which are morally approved. It is the consequences that call the tune: and motives are brought to the fore only because they can be counted upon regularly to produce beneficent actions. To have a sense of duty as one's primary motive for behaving well is rather to be deprecated, since this suggests that one is deficient in natural benevolence." See also MacIntyre, "Hume on 'Is' and 'Ought' ", Hume. Modern Studies in Philosophy. A Collection of Critical Essays (1968), p. 240 .

45. See Wand, "Hume's Account of Obligation", Hume. Modern Studies in Philosophy. A Collection of Critical Essays (1968), 308, at p.312. 
the performance of promises", of which the entire legal system is a mere elaboration. ${ }^{46}$ Hume urges us to accept these three principles out of fear of what might otherwise arise:

"' 'Tis on the strict observance of those three laws, that the peace and security of human society entirely depend; nor is there any possibility of establishing a good correspondence among men, where these are neglected. Society is absolutely necessary for the well-being of men; and these are as necessary to the support of society". ${ }^{47}$

"Rules of this sort", one commentator observes,

"must be recognised before people can come to agree or bind themselves by promise or contract to any form of government. Therefore though it be possible for men to maintain a small uncultivated society without government, it is impossible they should maintain a society of any kind without justice, and the observance of those three fundamental laws . . . These are, therefore antecedent to government, though government, upon its first establishment, would naturally be supposed to derive its obligation from those laws of nature, and in particular from that concerning the performance of promises." 48

The point that Hume wishes to stress - and it is here that his strict Scottish religious culture comes so clearly to the fore - is that for order to be maintained no regard can be paid to the individual. Only if the "inflexible rules of justice" are universally applied ignoring the particular merits of individual cases, only then will society as an organised body survive. Hume is very clearly pessimistic about the nature of man and his organisational ability, and grudging about his success in constructing a social structure. Hume believes in 'the shortsightedness of men, their propensity to prefer immediate advantage to distant gain, and their incapacity to be guided by a proper appreciation of their true long-run interest unless they bind themselves by general and inflexible rules which in the particular case are applied without regard to consequences." 49 This is a classic statement of at least one facet of the individualistic dogma, namely that firm - even blind - application of the rules (whether strictly speaking legal ones or otherwise) is ultimately to the benefit of all, even of those who fall by the wayside as a result of that very application. Laws, says Hume, "are not derived from any utility or advantage which either the particular person or the public may reap from his enjoyment of any particular goods. . . Justice in her

46. Wand, supra n.45, at pp. 346-7. Hume's emphasis is on the evolutionary nature of these 'rules of the game', followed first out of self-interest until eventually they take the force of law.

47. From the Treatise of Human Nature III (ii)6, quoted in A. Flew, David Hume: Philosopher of Moral Science (1986), at p.164.

48. Hayek, supra n. 18. at pp. 347-348.

49. Ibid., at p.348. 
decisions never regards the fitness or unfitness of objects to particular persons, but conducts herself by more extensive views. "50 Moreover, he admits, a single act of justice is even

"frequently contrary to the public interest; and were it to stand by itself, without being followed by other acts, may, in itself, be very prejudicial to society. . . . Nor is every single act of justice, considered apart, more conducive to private interest than to public. . . . But, however single acts of justice may be contrary, either to public or to private interest, it is certain that the whole plan or scheme is highly conducive to indeed absolutely requisite, both to the support of society and the welfare of the individuals". ${ }^{51}$

The approach that Hume takes to the origin of social institutions is thus, as Flew sums it up, "evolutionary as opposed to creationist; and a main insight of any such sophisticated understanding is that social institutions, which are of course purely human productions, may have functions and consequences which are not the fulfilments of anyone's intentions." "'Tis self-love," writes Hume in the Treatise,

which is their real origin; and as the self-love of one person is naturally contrary to that of another, these several interested passions are obliged to adjust themselves after such a manner as to concur in some system of conduct and behaviour. This system, therefore, comprehending the interest of each individual, is of course advantageous to the public; tho' it be not intended for that purpose by the inventors." 52

The similarity of this passage to the ideas of Adam Smith is unmistakable. ${ }^{53} \mathrm{It}$ is the fiercely defended individualistic notion (shared by, among others, John Stuart Mill) that society is healthiest when the role of government and of law (and,

50. Ibid., at p. 350 .

51. Ibid., at pp. 350-1. Compare this with Kant's conception of justice which basically consists of the application of the ius talionis. This rule, if strictly applied, is in Kant's view always beneficial to the individual concerned and to society at large, as it heeds the dictates of the summum bonum. "The law of punishment", Kant says,

"is a categorical imperative, and woe to he who rummages about in the winding paths of a theory of happiness looking for some advantage to be gained by releasing the criminal from punishment or by reducing the amount of it. Following the Pharisaic motto: 'It is better that one man die than a whole people should go to its ruin. ' For where legal justice perishes, then it is no longer worthwhile for men to remain alive on this earth."

(quoted in William, supra n.22, at p.98). Kant does however allow exceptions to be made when these are dictated by reason of state.

52. Supra n.47, at p. 159.

53. See A. Smith, An Inquiry into the Nature and Causes of the Wealth of Nations, passim, esp. IV (ii). 
one might add in a post-Weberian world, that of bureaucracy as well) is reduced to a minimum, and that the state should above all be wary of any unchecked tendency on its part toward paternalism. The greater benefit of all is achieved, according to this ideology, from the conflicting interests of the individuals at work in society, not by any planned process coordinated from above by an autocratic (even if wellintentioned) utilitarian agent, but as a result of the natural economic activity of man and his social interrelations. It is the classic Smithian free market at work not only economically but intellectually too and in every sphere of human activity. The advantage to the public, for all its importance, is "not intended for that purpose by the inventors", Hume reminds us, and is nothing more than a serendipitous by-product for the natural (and rightful) concern of each for his or her own.

\section{$\mathbf{V}$}

At the heart of Mill's individualism was his deep-felt distrust of government as a system $^{54}$ in the age of mass society. ${ }^{55}$ For this champion of individualism the distrust was in part undoubtedly caused by over-exposure to Benthamite utilitarianism in his youth and an intimate knowledge of it in all its forms. While espousing utilitarianism at its most abstract, he realised, having been witness at close quarters to the numerous plans set out by various eager Comtians and Benthamites, but above all to the variety of political, economic and legal schemes of Jeremy Bentham himself, that even the

54. Mill saw little need for governmental paternalism in the case of what he considered intellectually and culturally (and hence also morally) "advanced" societies. For the less "advanced", the situation was different and he himself, like his father before him, was an administrator at the India Office - a state employee on behalf of a "benevolent" government.

55. In part the deep-seated suspicion of government was a result of the changing nature of political society in the second half of the nineteenth century. Fear - or at the very least dislike - of the masses was one elitist aspect of classic liberalism that grew as government began to take heed of, later to represent, the views of the masses, albeit slowly in the nineteenth century but with increasing speed in the twentieth, particularly after the impetus to democracy given by the First World War. The elitist concern with the tremendous demographic and political surge of the masses was given classic voice by intellectuals such as Nietzsche in Also Sprach Zarathustra and, in the twentieth century, by Ortega y Gasset in The Revolt of the masses. Scion of an elitist Continental tradition, Ortega was no liberal. Neither of course, was Nietzsche..Kant too was subject to these fears:

"In the theory of the state, Kant attempts to combine the freedom and consent of Rousseau's Social Contract with the domination and absolute authority of Hobbes' Leviathan. He sets out from liberal, individualistic premises, but because of his fear of the power of unrestrained egoism and his general distrust of the people en masse, he concludes by giving his support to conservative and authoritarian principles."

(Williams, supra n.22 at p.161.) But similar concerns were voiced in mid-Victorian England by Carlyle and Matthew Arnold and their followers, and hints of it can be found in Mill as well. Mill's call for virtue and for the strengthening of the cultural premium placed on individualism reflected to no little extent concern with the "collective mediocrity" of public opinion, the force of which, he feared, could reduce England to the level of the Chinese, who "have succeeded beyond all hope in what English philanthropists are so industriously working at - in making a people all alike. ' Quoted in Semmel, supra n. 24 , at p. 170). 
most well-meaning system conceived with the sole aim of maximising the happiness of all would inevitably result in loss of personal freedom for the individual. ${ }^{56} \mathrm{To}$ the utilitarians, raised in the strong light of the empiricist tradition, happiness was predominantly a material question, and therefore readily amenable to mathematical and economic computations. ${ }^{57}$ But for Mill, and here once again the Kantian shadow looms large (as does the influence of Wilhelm von Humboldt and of Carlyle), liberty was primarily - or rather equally - liberty of the intellect. The "appropriate region of human liberty", he declared, was

"the inward domain on consciousness; demanding liberty of conscience, in the most comprehensive sense; liberty of thought and feeling; absolute freedom of opinion and sentiment on all subjects, practical or speculative, scientific, moral or theological. . ." 58

For Mill, as Isaiah Berlin writes, "individualism . . . (is) an ideal. Mill likes dissent, independence, solitary thinkers, those who defy the establishment." 59

But Mill's defence of liberty was also a call for individual virtue. ${ }^{60}$ Happiness and virtue have always jostled for primacy within the framework of the philosophical question of the nature of liberty, and by stressing the importance of virtue (although not at the exclusive expense of happiness) Mill parted company from the strict utilitarians. Ultimately, Mill could agree with Carlyle, at the most rarified altitudes of human existence virtue and happiness were one. But he disagreed with the ascetic prescription of Carlyle, Heavily influenced by German philosophy, of "entsagen, sacrifice and the renunciation of happiness", as the road to virtue. This might be a path suitable for Carlyle's Heroes, but a latter-day imitatio Christi was evidently out of the question for the majority of humanity. "While virtue insisted that each individual be conscious of the needs of others, men and women ought also to be able to pursue their own happiness, not always to be asked to think first of their duties to society. Increasingly, Carlyle came to see his call for a virtuous self-assertion as directed only to genius, only to the strong. On the other hand, Mill was to see selfrealisation as the proper goal for all." 61

The difference is crucial. Virtue, arguably, can be arbitered. The pursuit of happiness cannot. And so Mill was led to the logical conclusion that found its expression as

56. Ibid., at p. 185 .

57. This scientific approach was also at the root of early economic liberalism in the Ricardian mould on which Mill was educated.

58. J. Mill, On Liberty (1946), at p. 10. "Perhaps", Semmel observes correctly (supra n.24, at p.185), "it would be more accurate to say not that the Benthamites and Comtians failed to understand these threats to liberty, but that liberty was not one of their central values. They were dedicated to material happiness, to the general contentment of the masses to whom liberty, honour, and the other abstractions must always come after economic and psychological satisfaction."

59. Berlin, "John Stuart Mill and the Ends of Life", in Four Essays on Liberty (1969) 173, at p. 178.

60. See n.55, supra.

61. Semme, supra n.24, at pp. 13-4. 
the ideological centrepiece of On Liberty, namely that the state has no right to restrict an individual's actions for his own good, the only remaining admissible interference being the prevention of harm to others: "The only purpose for which power can be rightfully exercised over any member of a civilised community, against his will, is to prevent harm to others. His own good, either physical or moral, is not a sufficient warrant." 62

Mill's brilliant analysis of freedom in what is commonly regarded as the text of liberalism ${ }^{63}$ opened the door to the debate over what has come to be known as "negative", and "positive" liberty:

"The first of these political senses of freedom or liberty . . the negative sense, is involved in the answer to the question 'What is the area within which the subject - a person or group of persons - is or should be left to do or be what he is able to do or be, without interference by other persons? The second . . . the positive sense, is involved in the answer to the question 'What, or who, is the source of control or interference that can determine someone to do, or be, this rather than that?' The two questions are clearly different, even though the answers to them may overlap." 64

The distinction is clear: advocates of "negative" liberty place the utmost importance on the freewheeling nature of man's condition in a liberal society; proponents of "positive" liberty stress the creative and progressive aspects of liberal society without attention to which man's freedom is in danger of remaining barren. Both sides are cautious not to overstep certain limits, and while the philosophical and ideological divide is clear-cut, in practice (as is historically the case with most ideological battles) the boundary between the two camps is not always neatly drawn. For while the idea of "positive" liberty, less idealistic - or rather less utopistic - than "negative" liberty, has to be reined in constantly by the awareness of the dangers of paternalism, (i.e. the danger of throttling individual liberty out of excess care for the human condition), equally "negative" liberty, due to the force of its noble call, can all too easily slide into anarchism, to which it is closely related ${ }^{65}$ In practice however, the matter is often one of nuance and of emphasis, of the direction in which the fabric of the social organisation is to be pulled. And as is often the case with sister ideologies,

62. The limpid and forceful style of this famous passage from On Liberty conceals however a major pitfall, and the battle is still regularly pitched over the boundaries between what might legitimately be taken to constitute "harm to others" and the undue restriction of the liberty of the individual.

$63 . " . .$. it is still the clearest, most candid, persuasive, and moving exposition of the point of view of those who desire an open and tolerant society.": Berlin, supra n.59, at p.201.

64. Berlin, supra n. 35, at pp. 121-2. In contrast to the history of political thought in the English-speaking world, in German philosophy the idea of "positive" liberty was ultimately wrenched away from the sphere of the individual (witness the shift in the meaning of liberty from Kant to Hegel) and harnessed to the needs of the larger social group - the nation, the state, etc.

65. Anarchism, at least in the Anglo-American political culture, is liberalism taken to its logical extreme. 
the most heated debates are often over the line of demarcation, the point at which one person's protection from harm becomes the infringement of his neighbour's rights. Not coincidentally, this is in the most fundamental sense the principle of which the legal system is an elaboration.

Mill has traditionally been seen as the advocate of "negative" freedom. Even if we accept this view ${ }^{66}$ he can hardly be placed on the libertarian-anarchist fringe of liberalism. There are aspects of civil life that Mill thinks the state ought to control, thereby restricting the autonomy of the individual. Not all of these fit the scheme of the purely "negative" liberalism that one would be led to expect from Mill. Mill urges limitations on freedom even for the individual's own good, as for instance in the case of education. In this he is at one with Hume and even the Grand Old Man of free-market policy, Adam Smith. In fact it would be difficult to find any figure in the liberal gallery advocating a total civic free-for-all. And this is an important point. None were libertines (although this was a common accusation levelled against them), none were Epicureans; all believed in the progress of man and society ${ }^{67}$ and believed that the function of society was to aid humanity in its journey along the road to progress.

But whether "negative" or "positive", underlying liberalism is the crucial perception of society as a stable and reasonable body, workable in the most practical sense of the word. This is so regardless of whether the liberal's basic outlook with regard to the nature of humanity is as pessimistic as Hobbes' or as optimistic as Locke's or Rousseau's. Regardless of whether one sees the idea of the social contract in evolutionary terms, or along with Hume and with Kant regards it as a useful philosophical fiction that furthers the inquiry into the nature of civil society, ultimately liberalism can only survive in a liberal society. This is not tautological. Whilst it is self-evident that along with a non-paternalistic state structure goes the assumption that society has no need for tutelage, there is also the practical expectation - in counterdistinction to the philosophical assumption - that each individual will behave decently, whether by nature or by means of (usually negative) incentives to do so. And liberalism has always recognised the need for, indeed insisted upon, the protection of society from wrong-doing. 68

Mill did not see the ultimate goal of the freedom he advocated as allowing the individual to run wild - not even within the confines of his own house. In On Liberty he calls for the state to compel the paterfamilias to educate his children, and even

66. For a masterly study of Mill and a convincingly argued case to the contrary, see B. Semmel, supra n.24. 67. Hume was a sceptic who confessed to not being able, in the last resort, to come up with a clinching argument for morality; yet his work exudes the same (though perhaps a touch more subdued) humanistic confidence in the ability of society to develop unguided that we find in Adam Smith. Kant, despite his occasionally gloomy views of humanity ("nothing straight", in his famous dictum, "can be constructed from such warped wood as that which man is made of ") is a believer in the perfectibility of man and in the ultimate, although perhaps infinitely distant, triumph of the summum bonum.

68. No liberal has ever advocated the dismantling of the legal system on the grounds that it restricts individual liberty. 
for the state to limit the rights of an individual to marry if he has not the economic means to support a family. The reason according to Mill for these necessary limitations on freedom is that liberty has a role to play in the bringing about of progress. The goal of individualism was not to ensure a close approximation of the state of nature à la Rousseau. Rather it was to harness in the best free-market method the untapped capabilities inherent in the individual to improve society. ${ }^{69}$ Isaiah Berlin writes:

" what made the protection of individual liberty so sacred to Mill? In his famous essay he declares that, unless men are left to live as they wish 'in the path which merely concerns themselves', civilisation cannot advance; the truth will not, for lack of a free market in ideas, come to light; there will be no scope for spontaneity, originality, genius, for mental energy, for moral courage. ${ }^{70}$

And not surprisingly it is when he talks of the reasons for liberalism - in practice the effect that liberty has on the individual - that Mill is at his most Kantian.

The "self-evident" truth of the concept of laissez-faire is doubly powerful as an ideological anchor within the framework of the Anglo-American intellectual tradition. Here Bentham's utilitarianism and the classic Millean precept of self-interested rational judgment (everyone is the best judge of his or her own interests) finds cover under this ideological umbrella alongside the unique Anglo-American brand of individualistic anarchism as exhibited in passive resistance and civil disobedience, with its inherent suspicion of the state in any form, and its fundamental Tuckerian belief in society as in effect no more than the numeric sum of its disparate parts. ${ }^{71}$ This is true even when it appears in a Godwinian guise that approaches the quasi-religiosity of an anarchist utopian community. ${ }^{72}$

\section{VI}

True to its dual heritage of German idealism and English empiricism, Anglo-American individualism finds objections to good faith at both the principle and practical levels.

69. "Mill had always in mind his foremost political and social objective: the need to maintain liberty as well as progress and order if a good society were to be preserved": Semmel, supra n.24, at p.6. 70. Emphasis added. And Berlin continues: 'To threaten a man with persecution unless he submits to a life in which he exercises no choices of his goals; to block before him every door but one, no matter how noble the prospect upon which it opens, or how benevolent the motives of those who arrange this, is to sin against the truth that he is a man, a being with a life of his own to live. This is liberty as it has been conceived by liberals in the modern world from the days of Erasmus (some would say of Occam) to our own. Every plea for civil liberties and individual rights, every protest against exploitation and humiliation, against the encroachment of public authority, or the mass hypnosis of custom or organised propaganda, springs from this individualistic, and much disputed, conception of man." Berlin, supra n.35, at pp. 127-8.

71. Benjamin Tucker, the editor of the radical periodical Liberty, was perhaps the most notoriously individualistic of all American nineteenth-century anarchists.

72. William Godwin was the author of an Enquiry Concerning Political Justice, published in 1793. Despite its very evident awareness of the Revolution in France, it is strangely cold and inhuman in the almost Biblical notions of justice it describes. Not suprisingly, the book is noteworthy for the fanatical individualism it defends (it is ironic to note that Godwin was the husband of the early feminist Mary Wollstonecraft, author of The Vindication of the Rights of Women). 
To deal with the objections of principle first, these take many forms but their essence runs something along the following lines: Individualism (or liberalism) believes in the autonomy (moral, legal and political) of the human being in society. Society, pace Kant, is not an end in itself, and exists in order to serve the needs of the individual where strictly necessary (and it is at this point that each individualist either expands or narrows the list of concerns in which the interference of society in the life of the individual is permissible). However, as the purpose of civil society is ultimately to render the existence of the human being autonomous (and thus to dignify and honour human life), it is counterproductive to cosset and protect the individual overly from the realities of existence, thus denying the person the opportunity to stand on his or her own two feet in an independent and honourable fashion. The freedom of the individual is also the freedom to err, to fail, to learn from experience. Ultimately, it is in this manner alone and not through paternalistic attitudes that civilisation, and each of its members, can advance. By expanding the concept of good faith one is in danger of creating an individual over-dependent on civil society (via the law) to solve problems that each individual should solve on his or her own, and this is contrary to the best interests of the individual. This is the reasoning that is also at the base of perhaps the most typical of all liberal legal principles, that of volenti non fit iniuria. In the long run it is healthy for every person to come in contact with the realities of life, and it is not the role of society to protect the individual from them.

The second level of criticism focuses on the practical side. It is impractical, not to say impossible (this line of argument goes) to control the conscience of every partner in every transaction. It is difficult enough to do so at the formal stage, but to attempt this at the informal stage is a nightmarish prospect. But - and this is where the individualist part comes in - to try to accomplish this is worse than doomed to failure. For the real danger is that any attempt to clamp down on the shadier side of this aspect of social and economic activity could only be done at serious inconvenience to all, and would result in a grave and unwarranted limitation of the freedom of the individual. Furthermore, advocates of "negative" liberalism would stress, such a step goes beyond the bare minimum of the inevitable intervention of the state in private matters.

In answering these criticisms I shall also divide my response in two. Dealing with the criticisms of principle first: true, individualism (or liberalism) believes in the dignity of man, and that dignity and autonomy abhor paternalistic government. But while liberalism does not (and cannot) regard the state as an end in itself - only individuals are ends in themselves - liberalism does believe that the state has a function to play in the elevation (or restoration, depending on one's outlook) of human dignity to humankind. The state, then, cannot be merely a passive onlooker, and there are spheres of activity in which even the diehard believers in "the state as nightwatchman" think that the state has not only a right but the obligation to interfere. The physical protection of its citizens is an obvious case in point, as is sanitation, and so on. ${ }^{73}$

73. It will be recalled that the prophet of market economics, Adam Smith, was not against state intervention even in economic affairs; extreme economic individualism - e.g. that of Herbert Spencer or, for a contemporary example, that of Milton Friedman - is the exception, not the rule. 
But these may be said to be "technical" matters, in the sense that they do not affect so much the content of human existence and human autonomy as much as they lay the ground for its flourishing. ${ }^{74}$ And yet liberalism also supports the notion of the educational function of the state - in effect this is a case of individualism accepting the idea of the intervention of the state in something as private as the formation of the human mind and psyche. And strangely enough, for this intervention we find agreement across the liberal board. The reason is that liberalism puts a premium on morality and the education to morality. All the major liberal and individualist thinkers were, as we have seen, profoundly convinced of the importance of just and moral behaviour. None of them were philosophically speaking egoists or Stirnerian anarchists. To divorce individual responsibility and morality from their philosophy is to make a mockery of it. Therefore the individual with which individualism is concerned is not a mere homo economicus, nor is his autonomy merely financial. And his education in general, and education to morality in particular, is the key to liberal society as it is conceived. The extension of the principle of good faith serves in this respect a dual purpose: first, by educating individuals to morality by habituating them to acting morally and in a manner that is compatible with their human dignity. Second, it is worthwhile recalling that the concept of motivation is an integral part of the liberal legal system: civil society refuses to allow the individual to reap the rewards of intentionally criminal deeds. The expansion of good faith is, logically, a similar lesson in the same morality, namely that in the liberal culture there are human values that stand above ruthless economic gain.

In the contingency of existence unlimited freedom is a meaningless proposition. The evolution of morals and the furthering of the ethical experience imply increasing limitations to freedom. Are the two necessarily antithetical? Should not civilisation imply the promotion and enhancement - rather than the limitation - of freedom? The answer is that both are equally implicit in the concept of progress. Limitation of one person's freedom so as to promote another's freedom, limitation of the latter's freedom to promote the freedom of a third. People once they belong to the human consortium, are forced to recognise that others exist, which is the beginning of morality. The truth is recognised, as we have seen, by what is commonly taken to be the most "anti-social" of philosophical ideologies, individualism; it is also recognised by psychology.

In the case of contract, which presupposes some subordination of one party vis-àvis the other, it is important that such subordination adheres to the purposes of the legal system. This in turn presupposes a conception of the nature of human relationships, and some assumptions with regard to society's moral ordering. The American legal

74. Although this too may be debated. "It is true that to offer political rights, or safeguands against intervention by the state, to men who are half-naked, illiterate, underfed, and diseased is to mock their condition; ... What is freedom to those who cannot make use of it?" Berlin, supra n.35, at p.124. 
system often clings to the concept of the separation of law and morals ${ }^{75}-$ the one presumed to be a public concern, while the other strictly private. And yet it would be absurd to claim that the law does not have an implicit concept of morality; it often waives its own principles when these come up against another value system extrinsic to the court, but one that the latter recognises as deserving priority.$^{76}$ Inevitably, this graceful bowing out of precedence by the law implies, when considered with a cold and logical eye, the limitation of individual freedom (or rights) of the individual selfconscious and uncomfortable about it. The law is suitably, even painfully, aware of this. And yet, because of the formal dichotomy it purports to respect between the private and the non-private, the moral and the non-moral spheres, it also appears to be somewhat embarrassed by the measures it feels (morally) obliged to take. ${ }^{77}$ The strong reactions against good faith seem supported by objective considerations and reasoning. And yet at the same time, as Farnsworth concludes, in practice the American system is close to accepting a good faith norm in precontractual negotiations.

75. In Continental Europe, where for centuries authority was invested with a sacred character and often justified its tyranny with the claim of operating in pursuit of the triumph of virtue, the conception of a neutral law was seen as the victory of political freedom against institutionalised morals.

The neutrality, in fact, is more apparent than real. See G. Ripert, La Règle Morale dans les Obligations Civiles 4th Ed. (1949). The law regulates human conduct and therefore takes a stand in the conception of life, although this is not explicitly said and legal rules are presented as imposed by contingent needs so as to be obeyed also by those who have a different conception of life and morality. A few moral notions openly complement legal rules, or even impose themselves as legal principles (for example, good faith). Most are camouflaged by technical concepts to make them generally acceptable. The law (or rather its fictional personification as "legislator" of Continental systems) is supposedly a technician and not a moralist, but the two roles often intertwine.

It is now accepted in Continental jurisprudence that it is not possible to separate legal constructions from the historical conceptions that underlie them. It is also accepted that both legal rules and moral rules have a deontological and imperative nature. The notions that morals only concern the motives, and law only the external effects of actions, is rejected on the ground that the purpose of both is basically the same. It is believed that morals and law relate to human actions in their entirety, and represent the two branches of ethics. Since neither is by itself sufficient, a reciprocal integration is beneficial to both. 76. There are innumerable examples of this. To remain within the sphere of contract law, see for instance Kronman, "Paternalism and the Law of Contracts", 92 Yale L.J. (1983) 763. Kronman describes and defines the various categories of state "paternalism" in which the law steps in to limit (what initially appears to be) the rights of the partners to the contract. This despite the fact that (and this bears emphasising) contract law is often considered an "amoral" and emotionally barren legal field.

77. A different tendency can be seen in the concerns with moral principles elicited by Ronald Dworkin's conception of a moral dimension of the law. See R. Dworkin, Taking Rights Seriously (1977). (As a comparative curiosity, we should note in passing that Dworkin's argument that judges cannot but rely upon moral principles is practically identical to that of Georges Ripert, supra $\mathbf{n} .75$, who argues that judges, censors in fact, must necessarily rely upon moral principles, and do make moral judgements about rules and about conduct).

At the risk of generalising, one could however say that American lawyers and scholars view these moral theories with a certain degree of uneasiness, and show greater interest for more "dynamic" discussions on the social engineering function of the law. 
The sticking point is very clearly the principle of the matter. ${ }^{78}$ American law thus appears to be uncomfortable with the role of conscience which, true to its empiricist heritage, it regards as an abstraction. ${ }^{79}$ This unease, rationalised as a preference for knowledge derived from the real world, tends, to Europeans, to appear exaggerated, almost pathological. Whatever the manner in which one chooses to view the question of the separation between law and morals, the fact remains that both the common law and civil law are actually impregnated with moral concepts. ${ }^{80}$

As for the practical objections, one should start by pointing out that individualism has historically assumed an implicit standard of social behaviour (in the sociological sense) - a basis of a calm society in which each individual is master of his or her own destiny. ${ }^{81}$ In this, perhaps, it reveals its elitist eighteenth-century English origins before it was ideologically intertwined, as is well known, with the democratic ideals of the French Revolution to become in the nineteenth-century Anglo-American liberal philosophy in its recognisable form. But even in the nineteenth century, and arguably well into the twentieth, this assumption of overall social stability was limited to a vision of civil society that in fact accounted for only a meagre portion of the population: white, male, and of a certain economic standing. Historically it was primarily with them in mind that individualism was conceived. They (it was felt) certainly had no need for state tutelage. Their equality was unspoken, assumed rather than stated. The world we live in today is, to put it mildly, far removed from that of the eighteenthcentury English (or American) town and country. ${ }^{82}$

78. It is an indication of the dominance of the "amoral" legal culture that Farnsworth can claim with the same breath (supra n.3, at p.242) that "the common law's aleatory view of negotiations well suits a society that does not regard itself as having an interest in the outcome of the negotiations", hinting that society is not concerned so much with the outcome of the negotiations as with their being unhindered. 79. Compare this with the misrepresentation of individualism as upholding a non-moral position of the individual in society. The psychoanalytical parallel is also telling. Bruno Bettelheim, Freud and Man 's Soul (1982) deplores the expurgation from the English translations of Freud's work of "the soul " which he believes has contributed to its elimination from American psychoanalysis.

Not just in America, but in Western society in general, there is nowadays a repression both of the soul and of the fundamental reflections of the unconscious. It is a repression that attaches to intrapersonal relationships and sexuality, and from there to the ethical-legal aspects of human relationships. In great part the situation can be blamed on the superimposition of layers of defences through centuries of exclusivity of phallocratic values.

80. I will mention by way of example the American unconscionability, which has been remarkably liberalised in recent years, and allows extensive moral policing, and the French abus de droit.

The "abuse of right" is, after a fashion, a general principle of French law stemming from the moral realisation that the law does not give all rights, but rather that rights are given for social ends, and that betrayal of that purpose constitutes an abuse. It implies abuse of freedom.

For a discussion of this doctrine, see Ripert, supra $\mathrm{n}$.75. In his defence of the value of the "good old moral rule", Ripert suggests that attempts to define the abus and make the theory objective may be a conscious, or unconscious, effort to erase its moral character, out of fear that an appreciation of the morality of an action would be considered unscientific.

81. It is in this form that de Tocqueville, for instance, understood the essence of American individualism, leading (in his critical eyes) to the danger of political apathy of the individual in civil society.

82. For a discussion of the assumptions underlying liberalism, see D. Manning, Liberalism (1976). In Hume, the father of Whig liberalism, there a static and rigid element that is reminiscent of Newton, whose genius he admired and whose predilection for strict empiricism he shared. In his History of England, 
The assumption of the equal footing of the members of society is thus patently misplaced. But the point that I wish to emphasise here is that such an assumption today is not only wrong but foolhardy. For despite the changing world about it, liberalism has not changed in one of its most fundamental unspoken assumptions: it still needs a settled, reasonable and workable society in order to function on the empirical, practical level - the only important one. The social contract, rewritten afresh every day, is still the crucial underpinning of liberalism, and contracts and promises are still the stuff on which life in the liberal world hinges. "The uttering of the words", writes one contemporary English philosopher, heir to the liberal tradition, "is, indeed, usually a, or even the, leading incident in the performance of the act." ${ }^{83}$ It is no coincidence that liberal philosophers systematically return to deal with the question of promises (implicit and explicit) and their implications. ${ }^{84}$ Again, it is no coincidence that modern legal systems, pace Kant, recognise motivation and intent as an essential element in the judicial evaluative process. ${ }^{85}$ If functionability is the key to success of liberal culture, then it is crucial for society to look ahead (despite Kant's belief that individuals tend on the whole not to be able to see beyond their short-range interests) and secure its own stability. Just as, in economic terms, the reliability of a currency has not only economic but also profound social, psychological and political implications, so we should realise that safeguarding the reliability of contractual negotiations has profound implications for the stability of liberal society. It is true that volenti non fit iniuria. On the practical level however, it is well to bear in mind that for the sake of the survival of liberalism we should be concerned for the non volenti as well.

Clearly then (to return to good faith), to object to the laissez-faire argument inevitably entails a re-examination and re-evaluation in less than favourable light of the intellectual

his major historical study, Hume writes: "In Newton this island may boast of having produced the greatest and rarest genius that ever arose for the ornament and instruction of the species. Cautious in admitting no principles but such as were founded on experiment; but resolute to adopt every such principle however new or unusual ..." (quoted in Smith, supra n. 18). The same rigidity of thought can also be seen in Kant, for all his genius. Kantian justice is petrified, mathematical, and totally inadequate for the modern world (and probably was so for Kant's age as well). Indeed for all its strict anti-utilitarianism as an instrument in the service of the summum bonum, it is debatable whether Kantian justice is a moral virtue in any commonly understood sense at all. Mill in this respect is different; witness for instance his championship of the rights of women.

83. J. Austin, How to do Things with Words. The William James Lectures 1955 (1975), at p.8. Elsewhere this empiricist calls promises 'performative' sentences.

84. See for instance Treatise III(ii), where Hume deals with the problem of the obligation to keep promises with relation to both the dictates of morality and the evolution of human society. For a modern liberal philosopher grappling with this problem, see Prichard, "The Obligation to Keep a Promise", in Moral Obligation (1949) (pp. 169-179). Kant also deals specifically with the issue. Significantly, according to Kant what one acquires through a contract is not the terms of the contract but the right to (or expectation of) their fulfillment. Needless to say, Kant makes the point that the parties to the agreement should deal in good faith at all stages of negotiation, the precontractual one included. See Williams, supra $\mathrm{n} .22$, at pp. 111-2.

85. For a profitable discussion of Kantian motivation in its legal context see O. Nell, Acting on Principle (1975), p.66 et seq 
pillars that prop up the house of democratic belief. Non-intervention sustains the belief in the free market of ideas and the accompanying doctrine of free speech. And to the degree that laissez-faire is held to be the economic and political ideal, so is comprehensive economic planning equated with any form of outside (i.e. state) interference in the daily functioning of market and town hall.

The notion of forcing the duty of good faith in negotiations down the several throats of the negotiating parties is thus counter to the perceived natural ebb and flow of market activity which depends for its stability on egoistic and ruthless self-interest, and as a form of regulation from above it is "artificial" and "unnatural", and therefore to be avoided at all costs as inherently - because instinctively - suspect. The exceedingly alarmed (and alarmist) and scornful language of some of the critics is hardly coincidental. Classic statements, such as the one by Oliver Wendell Holmes to the effect that the concept of moral duty should be washed in "cynical acid", 86 reveal the unease of commentators with the inseparability of legal and moral duty. To transform altruistic behaviour into a legal duty would seem to go against the ingrained (male) American frontier culture and a widespread Darwinian and Spencerian spirit.

In this light the impression that positivist arguments of rational behaviour and descriptive law conceal a more fundamental objection to the notion of good faith is difficult to avoid. As Lon Fuller states candidly in his perceptive article "Positivism and Fidelity to Law": "the dominant tone of positivism is set by a fear of a purposive interpretation of law and legal institutions, or at least by a fear that such an interpretation may be pushed too far." 87 Ultimately, the lines are drawn on the question of connectedness (or lack thereof) between morality and the law. It is along this sharp divide that positions are defended with the utmost stubbornness and ferocity.

\section{VII}

The problem of the morality of law goes to the heart of the philosophy of law. Essentially it revolves around the questions or whether law has intrinsic morality, of whether moral criteria can be excluded from the concept of order, and of the nature of the authority of the law. Solutions to this age-old fascinating philosophical tangle have been suggested since Plato, if not earlier, and it would be presumptuous to claim to see the light where so many luminaries have not. But exhilarating as the philosophical question may be, one should not forget that law is not merely a theological or philosophical exercise, set apart from the real world of women and men. Legislation is man-made, the application and enforcement of laws devolves upon humans, and laws affect the lives of human beings. Law - secular or religious, modern or ancient,

86. O. W. Holmes, The Path of the Law (1897) in Collected Legal Papers (1920), p. 173

87. L. L. Fuller, "Positivism and Fidelity to Law - A Reply to Professor Hart", 71 Harv. L. R. (1958) 630 , at p:669. "I believe, though I cannot prove," he continues, "that the basic reason why positivism fears a purposive interpretation is not that it may lead to anarchy, but that it may push us too far in the opposite direction. It sees in a purposive interpretation, carried too far, a threat to human freedom and human dignity." Ibid., at pp. 670-671. 
just or unjust - is a creation of human society and part of it, and therefore is logically (but also by necessity) subordinate to human needs and exigencies. It is only on the basis of this understanding that the discussion of the moral content of law can have any coherence at all, other than as an aristocratic sparring match. To rephrase this point, the basic problem is one of allegiance: of whether fidelity to the law or the fidelity of law to morality is the greater duty. ${ }^{88}$

The case against morality in law involves two major arguments. The first is a formal philosophical one: that the law is a structure, an ordering of behaviour without intrinsic qualities of good or evil. As a structure it can be judged on the basis of its coherence and internal flow (or lack of internal contradiction), but not by its content which is a quality independent of structure. This is a powerful argument. It has the beauty and "music" of perfected legal systems on its side. But it lacks life. It is an argument that reduces law to a geometry replete with axioms and rules on which to build fanciful structures. And just as geometries have been developed for two, three and four dimensions without regard for the world of physics, so can flawless legal systems be invented for worlds of good, bad and indifferent humans. In short, this argument is one that profoundly rejects any concept of the contingency of the law and the need for it.

If the formal argument of the separation of law and morality can be refuted on the equally theoretical ground of the incompatibility between such a separation and the inherent purposes of laws and their function, another objection is possible on practical political grounds. Given the basic requirement of any legal system that laws be upheld, there are serious social and political repercussions when there is too great a discrepancy between the law and the common perception of justice. The classic case, and one that has received a lot of attention is that of the deterioration of the rule of law under the Nazi regime. ${ }^{89}$ It is not my intention to use this emotion-laden case as an admonition of what might occur if the concept of good faith is not expanded. But there cannot be a more forceful example than this one, of what happens when the law is divorced from morality. An extreme example, to be sure, but in itself it bears witness to the inevitable moral content of law. If "law surely is not the gunman situation writ large" but is based upon "fundamental accepted rules specifying the essential law-making procedures", those fundamental rules must have moral content to become accepted. "Law, considered merely as order, contains, then, its own implicit

88. "Law, as something deserving loyalty, must represent a human achievement; it cannot be a simple fiat of power or a repetitive pattern discernible in the behaviour of state officials. The respect we owe to human laws must surely be something different from the respect we accord to the law of gravitation. If laws, even bad laws, have a claim to our respect, then law must represent some general direction of human effort that we can understand and describe, and that we can approve in principle even at the moment when it seems to us to miss its mark." Fuller, supra n.87, at p.632.

89. See, for instance, Pappe, "On the Validity of Judicial Decisions in the Nazi Era", 23 M.L.R. 260 (1960); Legal Philosophies of Lask, Radbruch, and Dabin, Twentieth-Century Legal Philosophy Series, vol. IV (1950). Fuller's article "Positivism and Fidelity to Law" is in reply to Hart, "Positivism and Separation of Law and Morals", 71 Harv. L.R. 593 (1958). 
morality. This morality of order must be respected if we are to create anything that can be called law, even bad law." 90

Of the two major arguments against morality in law the first is formal. The second argument works on an exclusionary principle, namely that the domain of morality is elsewhere - in the individual, or in a higher law - and therefore cannot be within the law. This is a view that accepts a distinction between morality of duty and morality of aspiration, ${ }^{91}$ where the duties (the negative injunctions, the thou-shall-nots) are socially oriented and therefore within the jurisdiction of the law, while the aspirations, which take up the remainder of the moral gamut however defined, are a matter for the individual alone to decide. The function of the law, in this view, is to lay down the minimal ground rules for human action in society, in effect stating: "So much is obligatory. The rest is up to each individual, and a matter of free choice."

In essence this is an argument against seeing law as simply prescriptive, although it leaves unanswered the question of the foundations of principle upon which the nonprescriptive legal edifice is to be constructed..$^{92}$ But even if one were to regard laws as being essentially descriptive rather than prescriptive, that view in itself would necessitate a constant modernisation and updating of laws in order to bring them in line with society's concerns and needs. The whole system of the law is predicated on constant revision and renewal, and on the necessary expansions and restrictions of legal definitions and applications. The idea that a codified civil law system is static is illusory. Both the civil and the common law systems converge under the impact of the need to adjust to the modern world and its problems, and we are witnessing an inflation of statutes, as the law tries to reorder its weighty traditions. Anyone who espouses a descriptive view of the law cannot logically object to expanded good faith provisions on principle. At most, he or she may object that the time has not come for such an expansion, or that there is no social urgency requiring their immediate application. ${ }^{93}$

The case against prescriptive laws is one that deserves careful consideration. In part it draws us again to the discussion of the individualistic conception of social activity. In the Western tradition and particularly in its Anglo-American variant individualism is often held to be sacrosanct. ${ }^{94}$ One should ask, however, if instead

90. Fuller, supra n.87, at p.645.

91. L. L. Fuller, The Morality of Law (1964). "Somewhere along this scale (of moral issues) is an invisible pointer that marks the dividing line where the pressure of duty leaves off and the challenge of excellence begins. The whole field of moral argument is dominated by a great undeclared war over the location of this point": ibid., at p. 10

92. "We can . . know what is plainly unjust without committing ourselves to declare with finality what perfect justice would be like. . . . Since the morality of duty must inevitably incorporate standards borrowed from the morality of aspiration, there is neither occasion or warrant for drawing a clear line between the two moralities." Fuller, supra n.91, at pp. 10-12.

93. But this is a dangerous course of action to adopt. Stalling is rarely the optimal strategy available. 94. " . . . the freedom of contract image is enormously powerful. Notions of individualism still appeal to us, not only because of the power of our traditions, but also because such notions are, at least in part, a true description of human behaviour and aspiration": Feinman, supra n.3, at p.833. 
of raising the dignity of man as it claims to have done since Pico della Mirandola, it blinds us to the needs of others by helping us to maintain an artificial dichotomy between individual and community. It is a strange conception of morality that separates it into two unrelated spheres, the individual and the social. Human responsibility and conscience does not recognise the epidermis as its frontier. Nor, for that matter, does the law. 95

Part of the argument against prescriptive law consists of the attempt to safeguard so-called "freedom" at all costs. The claim is made that there is a need to protect the bargaining freedom of the parties, and that the imposition of a good faith requirement at the bargaining stage would curtail this freedom. It is a curious fact, however, that these defenders of freedom on the whole find themselves objecting sharply to the logical reduction of the philosophy of freedom, namely anarchism. This is because they recognise that human and social survival depend on reciprocity and mutual help, which are different terms for social responsibility. ${ }^{96}$ "I should like . . . to recall," Fuller reminds us,

\footnotetext{
"what we would lose if the concept of responsibility ever disappeared completely from the law. The whole body of the law is permeated by two recurring standards of decision: fault and intent. Philosophic discussion of these notions has largely concentrated on their role in the criminal law, where they have given rise to the most abstruse arguments, including that concerning freedom of the will. But these twin standards play an equally important role in the law of contract, torts, and property. Examined closely they turn out to be difficult and elusive conceptions in whatever area of the law they appear. Yet without them we would have no thread to guide us through the labyrinth. . . .

Notice what happens when these two tests, and their near relatives, fail completely. This occurs in the law of contracts when performance of an agreement is hampered or its significance is changed by some external event. . . . In the law of property our familiar standards fail when nature intervenes and takes control . . . In cases like these the litigants do not appear as responsible agents, but as the helpless victims of outside forces. We can no longer ask: Who was to blame? What did they intend? Since our usual standards of justice fail us,
}

95. Moreover, as Feinman remarks, "the individualist vision is only a partial vision; its characterisations of individual and social welfare do not accurately portray the aspirations of our people or our legal system. . . . Historically and today, we respect the person who can stand alone and take care of himself or herself. But we also have felt and do feel distaste for the person who is uninvolved in the community, the person who is selfish. The image of the selfless, caring person is powerfully attractive. Neither ideal alone accurately reflects social values": Feinman, supra n.3, at p.841.

96. In fact, even most forms of anarchism, with the notable exception of individualist anarchism, recognise the need for human cooperation. For the strange brand of anarchism that does not accept such bonds, see the classic nineteenth-century anarchist text by Max Stirner, The Ego and his Own, first published in Germany in 1845 .

Hostility to anarchism coupled with defence of classic liberal concepts also raises the suspicion that what is being defended is less a moral or ideological viewpoint that a vested interest in the status quo. 
we are at a loss to know what justice requires. If we were to lose throughout the law the view of man as a responsible centre of action, all legal problems would become like those I have just suggested." 97

The good faith provision requires each party to act with a modicum of decency vis-à-vis the other. In fact, at the present stage of human development, the duties that good faith imposes go beyond the minimal formal legal responsibilities of, say, not lying or not cheating, but do not demand the impossible. Good faith forces on us the recognition of the basic humanistic responsibility of decency.

\section{VIII}

The element of responsibility recognised in the law leads us to another important factor relating to morality within the framework of the law, and that is the moral responsibility of judges. One of the objections to a duty of good faith is that the superimposition of morality would necessarily entail supervision of human morality by the state. This would mean not only that the state at some level (the legal level) would be charged with deciding who is acting morally and who not (and presumably punish the immoral actor accordingly), but it would also be the judge of what morality is, and of what constitutes moral behaviour. While this idea is untenable throughout the Western world, the argument goes, it is particularly abhorrent in America, where the separation of Church (as presumed arbiter of morality) and State is a basic tenet of political philosophy, and where it has been given its greatest extension. The truth of the matter however is that judges are in fact the interpreters of the law, and therefore cannot lay claims to objective impartiality. ${ }^{98}$ They are the ones who bring the law - and justice - alive. Such an act of creation cannot exist outside of reality. Judges, therefore, have a clear responsibility to society. Their decision must take into account the aspirations and needs of society. 99 "Philosophers and linguists", Gillette claims,

"have criticised the belief that specific content can be derived from moral or normative phrases by analysis of the context in which those phrases are used. It is possible that 'good faith' is not susceptible to the type of perspicuous paraphrase that allows us to comprehend from ordinary usage of the term precisely what the speaker means. Indeed, it is probable that different judges will mean different things when using the phrase, thereby undermining any attempt to derive a single meaning or single principle from the combined usages. Moreover, even

97. Fuller, supra n.91, at p.169.

98. One of the defects of classical law, writes Feinman, "was the impossibility of achieving a truly formal, rule-based body of doctrine. The inadequacy of language and the complexity of facts made the ideal unrealisable; rules could not be both precise and comprehensive, so judges, not rules, decided the cases": Feinman, supra n.3, at 9, p.836.

99. "Within the limits of (the) structure (of the law), fidelity to law not only permits but demands a creative role from the judge, but beyond that structure it does not permit him to go." Fuller, supra n.87, at p.670. 
if all judges concur in a principle that embodies 'good faith', they may fail to make important distinctions in conduct." ।

The breathless rush of criticism and the jumble of arguments presented here is indicative of the fear of morality in law. It is compounded by inexplicable statements such as the following: "We may also have a concern that judges have neither the training nor the temperament to engage in the reflective process that arguably allows for extraction and justification of normative principles from vague phrases." 2 This is similar to a remark by a legal scholar with reference to Germany, according to whom good faith became "in the days of the great inflation following World War One a licence for judicial remaking of contracts way beyond anything that ever happened in the United States."' The implication here is that under the formal view of the role of the judiciary (application rather than interpretation of the law) there is no judicial discretion at work. This idea is illusory. "Adjudicating any contract case entails a decision about policy and value. Because they are more accurately embodied in standards than in rules, policies and values will be vague and, as applied in a particular case, overlapping or inconsistent. Thus, courts need a method for determining which values should prevail in a case and how those values should be applied." ${ }_{4}$ At any event, it would seem natural that exceptional, indeed catastrophic social, economic and political conditions would require drastic measures. That, of course, is not what is being recommended here. But such comments and attitudes may at best be taken as myopic and distrustful. At worst, if they are to be taken seriously, they are a suicidal self-indictment, and an accusing finger pointed at the whole practice of the law in all its current manifestations.

The role of the judiciary is increasing also due to the fact that the legal conception of contract is riddled with problems and inconsistencies. As the gap beween contract

1. Gillette, supra n.6, at p.645.

2. Ibid., at p.645, n.117. This calls to mind Bushwick-Decatur Motors, Inc. v. Ford Motor Co., 116 F.2d 675, 677 (2d Cir. 1940), in which it was stated that only legislators can properly impose obligations of good faith. This is a surprising statement coming from an American court (it is in the civil law rather than the common law system that judges are considered mere oracles of the law). Is this timidity exceptional, or are judges absorbing and internalising the suspicion of others toward them?

3. From A.L.I. Proceedings 489-91 (1970), quoted in Summers, "The General Duty of Good Faith Its Recognition and Conceptualization", 67 Cornell L.R. 810 (1982), at p.815.

4. Feinman, supra n.3, at p.708. In addition, "critics of the contract/no contract dichotomy also pointed out that contractual liability flowed not from agreement, but from judicial action: imposing contractual obligation necessarily involved legal coercion. To be sure, such coercion was employed to protect either a prior exercise of freedom of contract or the security interest of the other contracting party, but it was coercion nonetheless": ibid., at p.683.

5 . The paradigm of the discrete promise is grounded on a classical notion of individualism that attempts to protect the promisor's freedom of action and the promisee's security simultaneously. But the reliance paradigm of promissory estoppel rejects the classical bargain concept in favour of a tort-like notion of loss-shifting. The underlying economic image is different as well: the reliance paradigm embraces a new vision of an economy characterised not by discrete transactions among autonomous actors, but rather by integrated exchanges that require the imposition of precontractual liability": Feinman, supra n.10, at p.716. 
law and tort law narrows ${ }^{5}$ and the legal liabilities are more and more similar, the extent to which contract law serves social ends becomes increasingly clear. ${ }^{6}$ Some would argue for a distinction between individual and collective contracts. "There is ample justification for judicial reluctance to impose a general obligation of fair dealing on parties to precontractual negotiations", writes Alan Farnsworth.

"The common law's aleatory view of negotiations well suits a society that does not regard itself as having an interest in the outcome of the negotiations. The negotiation of an ordinary contract differs in this way from the negotiation of a collective bargaining argreement, in which society sees itself as having an interest in preventing labour strife. Although it is in society's interest to provide a regime under which the parties are free to negotiate ordinary contracts, the outcome of any particular negotiation is a matter of indifference."

This argument is questionable for two reasons. The first is that there is considerable danger in discriminating between individuals on the one hand and groups on the other, and giving preferential legal treatment to the latter. This is precisely the sort of legal discrimination against which defenders of individual freedom (of contract or of any other legal, social, political, or private act) protest. Its only possible justification is the good of society, but this again is a cause that promoters of individualism are wary of espousing. The second is that it is as difficult to discriminate between individual and society on the social and political level as it is on the legal. To say that although "it is in society's interest to provide a regime under which the parties are free to negotiate ordinary contracts, the outcome of any particular negotiation is a matter of indifference"', is akin to saying that despite deomocratic society's interest in overall free elections, fraud in any particular constituency is a matter of indifference. ${ }^{8}$ The foundations of democratic society and government are individual citizens. All modern political systems are founded on the principle of legitimacy (i.e. perceived or formal legality), and therefore isolation of the law from the social and political aspects of the law is unfeasible. ${ }^{9}$ The same is true of the economic system. "The system of

6. "There is evidence to suggest that classical scholars viewed freedom of contract not as an immutable principle, but as a policy choice at the system level. Thus, the essential difference between classical and modem law on this point is that classical law opted for private ordering as a general rule to avoid reintroducing social policy judgments at a lower level in the adjudication of individual cases. For the classicists, unlike the realists, this seemed like a natural policy choice - the unfettered capitalist market being naturally superior to socialism or anarchism": Feinman, supra n.10, at p.834.

7. Farnswerth, supra Part I n.3, at p.242. In fact collective bargaining is a continuing readjustment. It implies long-term relationships. What labour law wants to do is to require parties to set long-term relationships. This may well be a healthy thing to prevent industrial strife, but for individual contracts the question cannot be addressed in the same way.

8. Fraud goes to the process, while the outcome does not necessarily. The analogy may therefore not be technically exact.

9. Although the issue is of course a matter of degree, it is the underlying and largely unrecognised basic tenet that is the most preoccupying. 
exchange in an advanced capitalistic economy functions best by not relying solely on the accumulation of individual choice, but by regulating and assisting individual ch甲ice through legal intervention." 10 The right, within certain specific limits, of each such individual not to be imposed upon by the majority is mirrored in her right to equal justice even when she is not a member, say, of a union involved in collective bargaining or class action.

Finally, mention should be made of the preventive aspect of the good faith principle. It is puzzling that some critics of good faith have taken to claiming that a measure directed at curbing antisocial and irresponsible behaviour would result in an undermining of security and heightened uncertainty in contracts. Prevention is commonly accepted as a function of modern law. It is interesting to note that the country that is pioneering the concept of preventive law in order to limit litigation is the United States. Prevention is accrued if damages are substantial rather than symbolic. It was American law that led the way in this field too, in cases of malpractice. What then can be the objections to precontractual good faith? Can intent be said to commence only upon arrival at the contractual stage? Is this a realistic view of society, or of the way in which human beings function?"1

\section{IX}

We have seen, therefore, that the whole conception of societal behaviour, whether economic or political, is derived from the concept of the free market where goods and ideas are exchanged without let and with the least hindrance and surveillance on the part of government. As stated, the underlying belief is that in this world of individualism all is for the best. The view hinges upon the optimistic assumption that the free-for-all of the market place miraculously yields the optimal results for society as a whole (although, as Adam Smith would admit, and indeed regard with the grim approval of a Calvinist) it leaves some individuals, the weaker ones, by the roadside. But this assumption is unsound and untenable, and in fact is proven wrong daily. Not even the hardiest advocate of laissez-faire would call for the total dismantling of institutions such as social security and consumer protection (for instance

10. Feinman, supra Part I n.10, at p.843.

11. While it is correct to say that in recent decades Western society has accepted a certain degree of planning in the law, the question remains as to how far this should go and what the proper balance should be. At present the general position is not to intrude where the parties are still trying to strike their own balance. One could suggest that in situations in which the process of bargaining is going to be much more expensive for one side than the other, costs should be shared. This is an ethical and at the same time not an economically unwise proposition.

We should note however that by its just considering transaction costs, the economic analysis does not favour the attention that specific cases should receive. Our vision should be addressed to the specific and the individual. 
in matters such as the medicines approved for public use, products with high levels of ozone-damaging CFCs, or lead-emission in vehicles). And yet these would seem to be required from a strict application of the supremacy of the "rules of the market". The fact that some limitations on economic ruthlessness - if this is indeed what "freedom" means - are accepted by all, point to the inherent fallacies and failings of unbridled freedom of contract.

Freedom of contract is a magical and dogmatic proposition. It epitomises all that we wish to believe is true not only about the economic system but about our independent "freedom" as individuals. But in fact freedom of contract - whether economic, political or social - is a mythical and dangerous illusion. Mythical, because the market is not a free market, nor are human beings free agents. And dangerous because the perpetuation of this illusion is a licence for uncurbed selfishness and uncaring ruthlessness.

There is no denial that the legal system can only function properly within certain boundaries and that these limits should be maintained. But how far should these limits go? Are they (and the system with them) already stretched to the maximum? Should the limits not be tampered with for the sake of the preservation of the system, or is the system ready to go beyond the present limits? These are difficult questions to which there are no simple answers. It is often stated that should the system go beyond its present limits it would lose its "soul". But perhaps it should lose its soul in favour of acquiring a new one. Can we afford to take the risk? Can we afford not to? Clearly a courageous choice has to be made. It is difficult at this stage to pinpont the risks ahead, but I believe that the benefits would outnumber the risks. And while we cannot really predict the outcome of the courageous choice that has to be made, we should not be dissuaded from going ahead by the apparent present sanity of contract law. Since the general foundations of society are shaking because of the acceleration of technology and population growth, endemic poverty and hunger, the disrespect for nature and the destruction of our environment, and the persistent non-amalgamation of the changes that are occurring into the body of society, the social and political foundations upon which we stand are generally shaky. ${ }^{12}$ In consequence contract law is a structure that stands upon a shifting ground, and can only be as firm as the earth beneath it.

12. "Surely", writes Fuller, "it is not only in the affairs of everyday life that we need clarity about the obligation of fidelity to law, but most particularly and urgently in times of trouble" supra n.87, at p.637. 